\author{
IVANA SLIVKOVÁ \\ (D) https://orcid.org/ 0000-0002-6168-1327 \\ Uniwersytet Preszowski \\ Preszow
}

\title{
Tożsamość kulturowa w rusińskiej literaturze na Słowacji ${ }^{2}$
}

\begin{abstract}
Cultural identity in Rusyn literature in Slovakia
Abstract: Cultural identity is a very important part of national identity, as it defines the individual's place in society. The aim is to show the Rusyn national identity consolidated in the contemporary literary works and to define the symbolism used by the Rusyn authors to emphasise their belonging to that nation. The six basic areas into which post-1989 Rusyn literature in Slovakia is divided are the following: poetry dedicated to the emerging national identity; poetry and prose based on folklore; rural-themed prose; metaphorical poetry dealing with diverse themes; literature for children and young people; literary translations. Authors belonging to the individual groups prove with their works that aspects of national identity, self-identification and, in fact, national revival continue to resound strongly in contemporary Rusyn literature in Slovakia.
\end{abstract}

Key words: Rusyn literature, Slovakia, national identity, contemporary literature

\section{Między kulturą a tożsamością}

Kultura jest złożonym procesem i zjawiskiem społecznym (o czym m.in. Čeněk, Smolík, Vykoukalová 2016, 29) - uwarunkowanym społecznie, ale

\footnotetext{
${ }^{1} \mathrm{~W}$ artykule posługuję się terminologią stosowaną na Słowacji (Rusini), w Polsce tę mniejszość określa się jako Lemków - I.S.

${ }^{2}$ Niniejszy tekst pierwotnie ukazał się po słowacku pod tytułem Obrasy národnej identity v rusinskej literatúre na Slovensku w zbiorze: Dynamické procesy v súcasnej slavistike. Zborník príspevkov z. medzinárodnej vedeckej konferencie 3.-4. novembra 2016 (Acta Universitatis Prešoviensis. Slavisitcký zborník 2, Prešov 2016, s. 216-223). Zaproponowana wersja jest tłumaczeniem wskazanego tekstu - przeredagowanym i uzupełnionym. Artykuł wcześniej ani w całości, ani w części nie był publikowany po polsku - I.S.
} 
też oddziałującym na człowieka i kształtującym jego działalność w określonej grupie społecznej. Z tego powodu tożsamość kulturowa jest bardzo ważną częścia tożsamości narodowej, określa bowiem miejsce człowieka w danej wspólnocie wyobrażonej (por. Anderson 1997). Na szczególną uwage zasługuje identyfikacja z kulturą mniejszości narodowych, a więc sytuacja, gdy tożsamości kulturowe i narodowe państwa (czy też większości obywateli) i interesującej nas mniejszości są różne. W tym miejscu nie będziemy jednak zajmowali się państwowa polityką dotyczącą mniejszości; naszym celem jest pokazanie rusińskiej tożsamości narodowej utrwalonej we współczesnej twórczości literackiej oraz określenie symboliki, którą wykorzystują rusińscy autorzy w celu podkreślenia swojej przynależności narodowej. Kultura jako zjawisko społeczne podlega wpływowi wielu czynników, wśród których szczególną rolę odgrywają: autoidentyfikacja (psychologiczna oraz geograficzna), język, religia i inne filary tożsamości narodowej. Należy też mieć na uwadze, że sama kultura może być postrzegana dwojako, bowiem z jednej strony wpływa ona na pewne upodobnienie ludzi tworzących grupę społeczną, z drugiej zaś jest tym, co ich odróżnia od innych grup. Jak pisze Zygmunt Bauman, już Michel Foucault twierdził, że tożsamość człowieka nie jest mu dana i dlatego poszczególne jednostki musza ją w trakcie swojego życia stworzyć, w podobny sposób jak tworzy się dzieło artystyczne (Bauman 2010, 64). Z punktu widzenia psychologii kultura jest wynikiem dawnych zachowań ludzkich, ale jednocześnie warunkuje zachowania przyszłe (Berry, Poortinga, Segall 2002). Biorąc pod uwagę przedstawione tutaj pokrótce określenia, za filary kultury uważać można: język, mentalność, etniczność oraz system wartości danej grupy ludzi; chodzi tu o tzw. kulturę etniczna, ewentualnie kulturę narodową (Průcha 2010, 31).

Analizy teoretyczne oraz próby opisania historii literatury rusińskiej na Słowacji (np. Blichová 2010) pokazuja, że problematyka narodowościowa wciąż należy do najważniejszych tematów rusińskiej twórczości artystycznej. Możemy przywołać liczne przykłady zarówno z poezji, jak i z prozy, które potwierdzają fakt, że Rusini bardzo silnie identyfikują się ze swoją narodowością, także w perspektywie historycznej - niezależnie od państwa, w jakim przyszło im żyć. Kwestia tożsamości narodowej jest więc obecna (w różnorodny sposób) prawie w każdym dziele współczesnej literatury rusińskiej na Słowacji. Najczęściej są to obrazy inspirowane wspomnieniami autorów z czasów dzieciństwa (twórczość takich pisarzy, jak Mikúláš Kseňak, Melania Hermanová, Mária Girová), które naznaczone były podziałami społecz- 
nymi oraz zawirowaniami historycznymi. Warto jednocześnie zauważyć, że współcześnie różnice (społeczne, statusu itp.) między poszczególnymi nacjami żyjącymi na Słowacji nie są duże. Dawniej Rusinów kojarzono z druciarzami, będącymi nawet przez jakiś czas swego rodzaju „symbolem” tej mniejszości (warto w tym miejscu przywołać trylogię o druciarzach Mikuláša Kseňaka), lub z innymi robotnikami wyjeżdżającymi w poszukiwaniu pracy - najczęściej do Ameryki. Byli to przede wszystkim ludzie ze wsi, których do wyboru emigracji doprowadziła wyboista i skomplikowana droga życiowa (zarówno ta jednostkowa, osobista, jak i ta społeczna - np. ich udziałem były przesiedlenia, zatopienia wsi itp., por. np. twórczość Marii Mal'covskiej).

Tożsamość kulturowa, definiowana jako świadomość przynależności do określonej kultury i akceptowanie oczekiwań otoczenia, jest częścia tożsamości grupowej, którą tworzą w takim samym stopniu jednostki, jak i grupy społeczne. Obserwujemy więc „współużytkowanie”, a także przejmowanie pewnych cech społecznych i kulturowych (Slivková 2015). Tożsamość rozwija się sukcesywnie, a najwyraźniej identyfikowana jest w styczności z inną kultura, np. w środowisku wielokulturowym. Odnosząc się do rusińskiej tożsamości czy kultury, interpretując je, nie można bezrefleksyjnie stosować zasad postępowania ani strategii wykorzystywanych w komunikacji międzykulturowej ${ }^{3}$, należy je dostosować do specyfiki środowiska wielokulturowego, ale jednak w większości słowiańskiego, mającego pewne wspólne cechy. Przeważająca większość Rusinów żyje w krajach słowiańskich (Słowacja, Polska, Ukraina) lub obok innych słowiańskich mniejszości (Węgry). Jednak nawet w tym kontekście możemy sięgnać do niektórych interesujących aspektów teorii komunikacji międzykulturowej, jak: obecność stereotypów, wzorców kulturowych i uprzedzeń w poszczególnych kulturach, które wchodzą we wzajemne relacje. $\mathrm{Na}$ tej właśnie problematyce chcemy skupić się w pierwszej części prezentowanych rozważań.

\footnotetext{
${ }^{3}$ Komunikacja międzykulturowa to komunikacja dwóch lub więcej kultur, których podstawa jest nie tylko znajomość języka obcego, ale także znajomość specyfiki kulturowej różnego rodzaju, co w konsekwencji pozwala na wybór odpowiednich sposobów zachowania. Jest to związane z potrzebą nie tylko jak najlepszego poznania innej kultury, ale przede wszystkim poznania samego siebie. Uwzględnianie specyfiki kulturowej jest szczególnie ważne w bardzo odmiennych kulturach. Uprzedzenia i stereotypy kulturowe moga jednak również powodować poważne nieporozumienia w stosunkowo podobnych i bliskich grupach (za: Průcha 2010).
} 
My i oni

Zaczniemy od zdefiniowania przywołanych wcześniej terminów, a następnie pokażemy, jak funkcjonuja stereotypy, wzorce kulturowe i uprzedzenia w utworach literatury rusińskiej tworzonej na Słowacji. Stereotyp stał się narzędziem interpretacji świata, pozwalającym na kształtowanie opinii i postaw. Współcześnie pojęcie to jest wykorzystywane głównie w psychologii, etnologii, językoznawstwie, historii i pozwala przewidywać zachowania określonej grupy w konkretnej sytuacji oraz wyjaśnić percepcję obcej kultury w prowadzonych badaniach kulturowych i językowych. Wiele stereotypów narodowych ${ }^{4}$ stało się tak ważną częścią kultury, że ich pozycja jest porównywalna z pozycją ustnej twórczości ludowej. Takie stereotypy powstaja na bazie akulturacji i socjalizacji, więc można je uznać za pewne formy mitów i symboli. Ogromną rolę w rozpowszechnianiu stereotypów odgrywa, poza przekazywaniem ich z pokolenia na pokolenie, bezpośrednia obserwacja, a współcześnie w znacznym stopniu także wpływ mediów.

Naszym celem jest wykorzystanie takich utrwalonych, zakorzenionych stereotypów ${ }^{5}$ w wyjaśnianiu tzw. wzorców kulturowych, charakterystycznych dla kultury rusińskiej. Wzory kulturowe to system takich form zachowania, którymi rządzi się dana społeczność kulturowo-językowa. Wymienić należy takie czynniki, jak np. system wartości, zasady moralne, prawa, tradycje, a także społeczne tabu. Jednak zachowania komunikacyjne są w znacznym stopniu subiektywne i mocno uwarunkowane przez naszą osobowość, temperament, wrodzone cechy i zdolności, które charakteryzują nas jako jednostkę odmienną od innych. Między stereotypem a uprzedzeniami istnieje bardzo cienka granica. Uprzedzenie jest definiowane przez Jana Koseka jako „negatywna, wręcz wroga postawa wobec człowieka należącego do określonej grupy tylko dlatego, że należy do tej grupy" (Kosek 2011, 23). Z tego właśnie powodu można niektóre negatywne stereotypy uznać za uprzedzenia. W rezultacie negatywne stereotypy, czyli uprzedzenia, są w większości związane z innymi, przy czym stereotypowa samoocena jest zazwyczaj pozytywna. Ten tradycyjny podział opisuje również Košt’álová, wymieniając dwie podstawowe kategorie stereotypów etnicznych: autostereotypy i heterostereotypy (Košt’álová 2012, 47). Autostereotyp jest wyobrażeniem, które ma-

\footnotetext{
${ }^{4}$ Košt’álová w tym kontekście używa również określenia „zbiorowe stereotypy” (Košt’álová 2012, 35).

5 Według Košt’álovej również skodyfikowane stereotypy (Košt’álová 2012, 37).
} 
my o swojej własnej grupie, a heterostereotyp jest wyrazem tego, jak postrzegamy innych. Opozycje 'nasz - obcy' albo 'my - oni' nie sa niczym nowym w literaturze. W teoriach interpretacyjnych taki podział istniał od dawna, ponieważ postrzeganie siebie samego odbywa się zawsze poprzez porównanie $z$ innymi.

\section{Tożsamość narodowa Rusinów we współczesnej prozie}

Zgodnie z przywołaną teorią (uznając jednocześnie za filary tożsamości narodowej w pierwszej kolejności język, religię, stosunek do wiary oraz samoidentyfikację światopoglądową i geograficzna) możemy stwierdzić, że bardzo dobrą egzemplifikacja rusińskiej tożsamości narodowej jest np. twórczość Marii Mal’covskiej. Pisarka ta jest postrzegana na Słowacji przede wszystkim jako popularna autorka literatury rusińskiej, potrafiąca zainteresować złożonymi postaciami kobiet, emocjonalną poetyką oraz aktualną problematyką swoich utworów. Chociaż nie jest uważana za pisarkę zajmująca się przede wszystkim problematyką narodowa, to jednak naród rusiński jest ważnym tematem w jej twórczości, a odwołania do jego charakterystycznych cech odnajdujemy w wielu jej tekstach. Dobrym przykładem jest identyfikowanie się z przestrzenią geograficzną widoczne w opowiadaniach autorki zatytułowanych Rusinske arabesky (Rusinskie arabeski, 2002), a także w powieści Zelená fatamorgána (Zielona fatamorgana, 2007). Rusini w jej opowieściach należą do środowiska wiejskiego - i nawet kiedy przekroczą ,granicę domu" czy żyja w innym miejscu, w sercu pozostają lokalnymi patriotami. Taki był los młodej studentki z Zielonej fatamorgany, podobnie rzecz się miała z bohaterkami Rusinskich arabesek, jak np. z docent Vasilina z opowiadania Medved'ko (Niedźwiadek). Wszystkie drogi ostatecznie doprowadziły te postaci do domu. Wieś i obszar wschodniej Słowacji uważane sa tradycyjnie za przestrzeń życiową typowego Rusina.

Twórczość Mal’covskiej pozwala również przyjrzeć się problematyce religijnej. Rusini Mal'covskiej (a zwłaszcza Rusinki) są dumnymi wyznawcami grekokatolicyzmu, co deklaruja także na zewnątrz, nawet w kulturowo i religijnie zróżnicowanym środowisku miejskim (widać to np. w pozdrowieniu Il'ky czy też przełomowym momencie opowieści - próbie sprzedaży ikon przez Svetikova w utworze Zielona fatamorgana). Wreszcie trzeba też 
uwzględnić samoocenę Rusinów (ważne stanowisko: dyrektor, prawniczka, docentka; siła osobowości: matka, samotny bohater w walce przeciw wszystkim itp.), w której odzwierciedla się typowy autostereotyp: „ciężką pracą osiagamy sukcesy".

Identyfikację z obszarem geograficznym jeszcze wyraźniej widać w utworze Mikuláša Kseňáka Spomienky a očakávania (Wspomnienia $i$ ocz̨ekiwania, 2013). Autobiograficzne historie rozgrywają się w rodzinnej wiosce autora, Kamience. Nawet wtedy, gdy główny bohater dostaje się na studia w Preszowie, a później przenosi się do Pragi, atmosfera wsi i jej typowe cechy (zaufanie, otwartość, bezpośrednie relacje) są stale obecne: „Szkoła poza Kamienka, życie poza rodzinną wioska... była to i ciekawość, i obawy" (Kseňak 2013, 72)6. Miasta, do których przybywają młodzi Rusini, aby się kształcić, są typowymi środowiskami wielokulturowymi, gdzie razem studiują Rusini, Słowacy, Czesi. Młody student w naturalny sposób wybiera znajomych z innych rusińskich wiosek (Čirč, Osturňa, Ladomírová, Legnava itd.); ich wzajemne relacje rozwijają się na podstawie podobieństw, ale w większym stopniu na podstawie kontrastów względem innych grup. Stereotypowe wizje i uprzedzenia są nieodłączną częścia postrzegania rusińskiej tożsamości narodowej. Widzimy to między innymi w opowiadaniach-wspomnieniach z lat dziecięcych, w których autor pokazuje różnice narodowościowe (przede wszystkim w opowieściach o obecności żołnierzy w rodzinnej Kamience). W opowiadaniach Kseňáka problematyka religijna jest tak samo ważna, jak w twórczości Málcovskiej. Na przykład bohaterowie często polegają na Bogu: „Nie masz Boga w sercu? Jestem pewna, że Bóg do tego nie dopuści. Bój się Boga, Mario!” (Kseňak 2013, 92), a pozycja duchownego jest bardzo wysoka; obok rodziców i nauczyciela należy on do największych autorytetów społecznych.

Jako trzeci przykład wybieramy opublikowane w 2015 roku dzieło Melanii Hermanovej Det'om pre radost' a poućenie (Drieciom dla radości i nauki), w którym także wyraźnie widać wspomniane już tendencje. Ciekawym przedstawieniem relacji międzykulturowych jest opowiadanie o bogatej wdowie, którą chcą zdobyć mężczyźni różnych narodowości (Czech, Polak, Węgier, Ukrainiec). Kobieta ocenia poszczególnych zalotników nie według osobistych sympatii lub antypatii, ale według ich przynależności do danej nacji. Autorka wykorzystuje tu nie tylko stereotypy, ale także uprzedzenia - zarówno narodowe, jak i społeczne. Podobnie stereotypowe przedstawienie narodowości

${ }^{6}$ Wszystkie przywołane cytaty w przekładzie autorki artykułu - przyp. red. 
(w tym przypadku chodzi wręcz o banał) znajdujemy w opowieści o kupowaniu świń, w której pojawiają się cwani handlarze pochodzenia żydowskiego. Problematykę tożsamości narodowej dostrzec można w opowiadaniu Mama, akej som národnosti? (Mamo, jakiej jestem narodowości?), w którym zastosowana została podstawowa zasada komunikacji międzykulturowej, tj. porównywanie się z innymi. Młoda Melanka, która dostała się do szkoły w innym kraju (Czechy), sama odkrywa prawdę o swoim pochodzeniu. Sama też zrozumie swoją odmienność. Rusińską tożsamość przyjmuje w sposób naturalny, a nie na podstawie zdobytej wiedzy czy chęci naśladowania sławnych rodaków z historii. Ciekawą częścią tej opowieści jest także niejednoznaczne postrzeganie bohaterki przez jej nowe środowisko. Czesi - koledzy z klasy nazywają rusińską dziewczynę Rosjanką ze względu na język, którym się posługuje, nauczycielka zaś Słowaczką, biorąc pod uwagę kraj pochodzenia dziewczynki. Także w tej historii pojawiają się oznaki autostereotypowej pozytywnej oceny, np. wujek Rusin, u którego Melanka mieszka, osiagnął wysoka pozycję; rusińska dziewczyna szybko uczy się czeskiego i z tego powodu zyskuje podziw. Podobnie jak w przypadku dwóch poprzednich autorów, również w twórczości Hermanovej odnajdujemy wyraźną identyfikację z obszarem geograficznym. Autorka przedstawia swoich bohaterów jako ludzi ze wsi o typowych cechach charakteru, zaś miasta w niektórych przypadkach stawia niejako po przeciwnej stronie (np. czeskie miasto Cheb i rusińską wioskę Habura).

Mikuláš Kseňak w zakończeniu książki Spomienky a očakávania (Wspomnienia $i$ ocz̨ekiwania) pomieścił refleksję dotyczącą rusińskiej przyszłości. Opisał sukcesy, jakie Rusini (jako mniejszość) osiagnęli na Słowacji, ale przedstawił także obecną sytuację, która charakteryzuje się zanikającymi szkołami narodowościowymi, „słowakizacja” duchownych, obrzędów religijnych itp. Rusini mówią o sobie w następujący sposób: „Typowa dla nas była robota, modlitwa i cicha cierpliwość" (Kseňak 2013, 133). Pracowitość i cierpliwość to, zdaniem autora, szansa rozwiązania problemów, z którymi rusińska mniejszość boryka się do dziś. Jednocześnie pisarz wzywa do jedności, w niej tkwi bowiem siła Rusinów - nie tylko tych mieszkających na Słowacji, ale także zrzeszonych w międzynarodowych organizacjach. Prezentując swoją wizję przyszłości Rusinów, Kseňák odnosi się do jednego z najczęściej poruszanych tematów, a mianowicie do języka: edukacji, obrzędów religijnych, rodziny. W większości dzieł literatury rusińskiej na Słowacji spotykamy się z tą problematyką. Autorzy namawiają do posługiwania się językiem rusińskim także poza domem rodzinnym, co ma być widocznym znakiem 
poczucia dumy z własnego pochodzenia. Przejawem takiej postawy pisarzy jest współczesny trend pisania wyłącznie w języku rusińskim (a od 1995 r. także w jego skodyfikowanej postaci). Autorzy młodsi, mimo sprawnego posługiwania się językiem słowackim, tworza po rusińsku. Starsi z kolei, piszący wcześniej w języku ukraińskim czy słowackim, stopniowo na język rusiński przechodza (Mal’covská, Suchý, Gicová Micovčinová, Morochovičová Cvyk i in.). Młode pokolenie autorów i tłumaczy (Lacová Hupcejová, Blichová, Semancová i in.) stara się wprowadzać innowacje językowe, przejmować obce słowa i tworzyć nowoczesną postać języka rusińskiego, która dostosowuje się do wymogów współczesności i będzie silnym argumentem w polemikach z zarzutem ograniczonego zakresu spraw, o których można mówić i pisać po rusińsku.

\section{Humorystyczna autorefleksja Rusinów}

Wspomniane wcześniej elementy, składające się na rusińską tożsamość narodowa, pojawiaja się w twórczości znanego rusińskiego autora Štefana Suchégo. Można je odnaleźć przede wszystkim w jego twórczości dla dorosłych oraz w utworach dla dzieci. Wykorzystuje on (w pewnym stopniu) edukacyjną funkcję literatury i stara się wzbudzić u młodych czytelników dumę ze swoich korzeni. Podkreśla także naturalną potrzebę używania języka rusińskiego jako pełnowartościowego wariantu języka kraju, w którym mieszka mniejszość. Utwory Suchégo są częścią tzw. dziecięcej literatury obowiązkowej, a ich podstawowym celem jest podniesienie prestiżu języka rusińskiego. Główną cechą tej twórczości jest humor i łatwość przedstawiania dostępnej czytelnikowi rzeczywistości jako naturalnej części ludzkiego życia, często także sięga po typową dla literatury dziecięcej personifikację.

Tematyka twórczości Suchégo, czy to tej przeznaczonej dla dzieci, czy dla dorosłych, skupia się na uniwersalnych dla świata judeochrześcijańskiego prawdach (które widoczne są także w znanych przysłowiach i powiedzeniach: gdzie dwóch się bije, tam trzeci korzysta; nie trzeba mieć siły, wystarczy rozum itd.), co widać m.in. w następujących utworach: V rabec a sova (Wróbel i sowa), Az̧uková Mama (Mama z. cyrylicy, 2010, zbiór), Haśterivá svokra (Swarliwa tésciowa), Pieseň o starej dievke Anči (Pieśń o starej pannie Anča), Chlap si myslí (Chłop sobie myśli) ze zbioru Rusinsky spevnik (Rusiński śpiewnik, 1994). W swojej twórczości dla dzieci opisuje także różnice międzykulturowe (np. w zbio- 
rach Azbuková mama i Rusinsky spevník) czy rusińską świadomość narodową w sposób przystępny dla dzieci, jak w opowiadaniu Ja som malá Rusínka (Jestem mata Rusinka) ze zbioru Slon na Kyčere (Stoń na Kyczerze, 2007). Suchý nie stroni także od krytyki społeczno-politycznej (Dedinský filozof / Wiejski filozof ze zbioru Rusinsky spevnik), humorystycznych wspomnień ( $V$ autoservise / $W$ autoserwisie czy Plody jesennej zábrady / Plony jesiennego ogrodu, 2016). Bohaterowie opowiadań Suchégo, w porównaniu z bohaterami innych rusińskich autorów, charakteryzują się inteligencją i sprytem. Skupimy się na analizie i interpretacji tekstu Ako Rusini relaxujú (Jak Rusini odpoczywaja, 1997, reedycja 2017), w którym pojawia się większość wymienionych wcześniej aspektów, jak: kulturowe wzorce rusińskie, podział my - oni, związek z miejscem zamieszkania (czyli autoidentyfikacja geograficzna), problematyka języka, poetyka rusińska (tj. wspólne cechy literatury rusińskiej na Słowacji), a także charakterystyczne już dla autora: ironia $i$ humor (na planie fabuły: spryt i inteligencja jako jedne z cech odróżniających Rusinów od dominującej populacji).

W zbiorze opowiadań Suchégo Ako Rusini relaxujú (Jak Rusini odpoczywaja, Suchý 2017) dominują dwie odmiany komizmu, mianowicie humor i satyra. Już w rozpoczynającym książkę opowiadaniu $O$ pekelnom capovi $(O$ piekielnym capie) czytamy: „żaden naród na świecie tak nie lubi cudów, jak nasi Rusini żyjący w małych wioskach położonych wśród lasów" (Suchý 2017, 3). Opowiadanie to, oprócz wiary w istoty nadprzyrodzone, odzwierciedla także bogobojność Rusinów, przerażonych diabelskimi znakami (czerwony cap). Nie chodzi jednak o żadne mityczne objawienie ani o posłańca piekieł, ale o żart młodych chłopców, którzy chcieli przestraszyć często popijającą staruszkę. Ważna jest tu także myśl, że przed siłami nieczystymi można ochronić się jedynie mocą modlitwy i wiary. Staruszka jest prześladowana przez kozła, własne zwierzę domowe, a nie przez siłę nieczysta; ona jednak tego nie widzi z powodu upojenia alkoholowego. „Powagi” żartowi dodaje czas, w którym ma miejsce wydarzenie - jest to przełom starego i nowego roku, a więc czas dokonywania życiowego bilansu i jednocześnie oczekiwania.

Głównym bohaterem opowiadania Hriech a pokánie Jurka... (Græech i pokuta Jurka..., Suchý 2017, 11) z tego samego zbioru jest tytułowy Jurko, który udaje martwego, ponieważ chce sprawdzić, czy żona go kocha. W żarcie pomagają mu przyjaciele, którzy trzymają straż przy nim aż do dnia pogrzebu i ukrywają tajemnicę dotąd, dopóki sam się nie zdecyduje jej ujawnić. Udawanie śmierci przyniosło oczekiwane rezultaty, gdyż wszyscy mieszkańcy wsi uwierzyli, że Jurko nie żyje. Opłakuje go nie tylko wystawiona na próbę żona, ale też kobieta, której Jurko potajemnie pragnie. Historia toczy 
się dalej, bowiem podczas pogrzebu Jurko wstaje z martwych i zaczyna nauczać ludzi o karze za grzechy, o niebie i piekle. Wymyśla różne sposoby odpokutowania ziemskich grzechów, wykorzystując wiedzę, jaką ma o ludziach ze wsi. Zyska nawet miano jasnowidza, bo nie tylko przepowiada przyszłość, ale też kary za grzechy. Jednak sława stopniowo zaczyna Jurka przerastać, więc zachowuje się niewłaściwie, przede wszystkim sam nie stosuje się do zasad, które deklaruje. Zdradza swoją żonę. We śnie zjawia mu się św. Juraj (Jerzy), który ostrzega go przed takim postępowaniem i prosi, aby przestał przepowiadać, kłamać i oszukiwać. Jurko przestraszy się i posłucha. Nie chce jednak przyznać się do winy, toteż planuje zakończyć nieuczciwą działalność kłamstwem i figlem, rozstanie się także z kochanka. Jedynie swojej żonie wyjawi, że ją zdradzał, a ona z kolei odkryje przed nim swój sekret (też go zdradzała, jeszcze gdy przebywał na emigracji w Ameryce; jej kochanek był mężem kochanki Jurka). Na koniec wybaczają sobie nawzajem.

Jedynym, przy kim Jurko traci odwagę (bariery moralne) i komu nie chce powiedzieć, jaka kara czeka go po śmierci, jest ksiądz wielebny, którego nie ośmiela się oszukiwać. Unika go i wymyśla powody, dla których nie może mu nic powiedzieć. W końcu tak bardzo urazi kapłana, że wielebny zadenuncjuje Jurka, przez co bohater trafia do więzienia. Na ścianie więzienia znów ukazuje mu się św. Juraj i przypomina mu przesłanie: „z prawdą ciężko się kroczy przez życie" (Suchý 2017, 64). Jurko swoją karę w końcu odbędzie i zrozumie też, że idea wszechobecnej obecności Bożej mocy, sprawiedliwej kary i rozgrzeszenia nie leży w rękach człowieka. Ciekawą częścią tej historii jest przedstawienie relacji damsko-męskich, które są podstawą żartu, a tym samym siłą napędową opowieści, bowiem miłość własna i zazdrość sprowokują wszystkie inne wydarzenia, które wywrócą życie Jurka do góry nogami.

Istotnym motywem tekstów Suchégo, oprócz przywoływania stereotypów (np. dotyczących picia alkoholu), jest także identyfikowanie uprzedzeń, jak to ma miejsce np. w opowieści o żandarmie Fedorze (Suchý 2017, 65), której wstęp został poświęcony uprzedzeniom wobec funkcjonariuszy - stróżów porządku, których uważa się za głupich, złych i nieuczciwych. Poza przedstawieniem ogólnego negatywnego obrazu służb państwowych, autor pisze też o brawurze młodych funkcjonariuszy, którzy nie wiedzą, jak postępować z ludźmi, aby uzyskać, czego potrzebują (np. ważne informacje). Jednak żandarm Fedor jest człowiekiem z ludu i dzięki temu wie, jak postępować z ludźmi. Zawsze chodzi pieszo, więc wiele widzi i słyszy podczas swoich wędrówek. Okres jego pracy przypadł na czas powojenny, trudny dla 
społeczeństwa, ale dający także, paradoksalnie, możliwość ujawnienia się ze zdwojoną siłą mądrości i siły ludu zmuszonego do radzenia sobie z niełatwymi doświadczeniami. Opowieść osiaga punkt kulminacyjny, kiedy Fedor, chcąc wybrać sobie narzeczoną, decyduje się odwiedzić dom jednej z panien, gdzie wita go i gości jej matka. Nie chce ona jednak wydać swojej córki za żandarma, więc go upija i pozwala mu spać z twardym koszem zamiast poduszki pod głową (co traktowane jest jako potwarz). Nie było to jedyne upokorzenie - kobieta naśmiewa się z żandarma i rozpowiada o nim plotki. Fedor chce się na niej zemścić, a dzięki swoim obserwacjom i dobrym kontaktom z ludźmi wie, że wkrótce nadejdzie czas domowej produkcji alkoholu, co oznacza, że także matka niedoszłej narzeczonej będzie pędzić bimber, a zatem złamie prawo. Żandarm czeka więc na odpowiedni moment i przychodzi do kobiety, aby ją ukarać grzywną. Jednak podczas spotkania odkrywa, że oboje na wiele spraw patrzą podobnie i że niedoszła teściowa nie jest wcale taka zła. Ona także zrewidowała swoje uprzedzenia wobec niego.

Fabuła jest poprzeplatana humorystycznymi epizodami - jak np. kontrola pozwolenia na romską zabawę, opowieść o złym słuchu Fedora, co spowodowało pomylenie przezeń banderowca z Bajerovčanem - których celem jest „uczłowieczenie żandarma”, pokazanie jego pozytywnych cech, takich jak np. chęć niesienia pomocy. Służby porządkowe są tutaj przedstawione jako niezbędne do prawidłowego funkcjonowania społeczeństwa. Z drugiej strony ludzie (a zwłaszcza cwani Rusini) zawsze starają się ominać reguły i nagiąc prawo - i to nie tylko w trudnym okresie powojennym. W opowiadaniu obecna jest także krytyka miejscowej społeczności, jej nadmiernych ambicji, a także mściwości. Za naturalną część życia uważa się (nieraz nadmierne) spożywanie alkoholu, a także specyficzny dla Rusinów humor?

Satyryczną część dzieła Ako Rusini relaxujú (Jak Rusini odpoczywaja) tworzą historie skupione na krytyce różnych aspektów życia tej społeczności, takich jak: moralność (liczne przykłady niewierności), polityka czy ideologia (problematyka partyjna). W opowieści Ako sme boli na brigáde v Sovietskom zuäze (Gdy pracowaliśmy w cżynie spotecznym w Zwiqzku Radzieckim, Suchý 2017, 74) studenci otrzymali jako prestiżową nagrodę za dobre wyniki możliwość zobaczenia „wielkiego i pięknego” ZSRR. To, oczywiście, dla młodych ludzi kusząca perspektywa - na tyle, że ci, którzy takiej szansy nie otrzymali, nie wahają się i gotowi są nawet zapłacić za ten wyjazd. Wizyta w ZSRR okazała

\footnotetext{
${ }^{7}$ Można tu przywołać np. scenę, w której Fedor pyta niedoszłą teściową o wydobywający się z komina dym, sugerując, że być może jest on wynikiem pieczenia chleba, na co kobieta odpowiada, że wszystko, co człowiek ma na stole, jest chlebem (Suchý 2017, 69).
} 
się jednak dużym rozczarowaniem - chociaż studenci ciężko pracowali, mieli złe warunki mieszkaniowe i nie mogli się nigdzie zabawić, a część ich aktywności ograniczano tylko dlatego, że byli obcokrajowcami (np. kapiel w jeziorze, wygranie rywalizacji o lepszy program kulturalny). Żeńska część grupy także nie czuła się dobrze w „ojczyźnie rewolucji” - studentki negatywnie oceniły nie tylko okolicę, ale też miejscowych mężczyzn - niezdarnych i bezczelnych. Po powrocie do domu już „nikt nie wierzył, że naród radziecki jest dla wszystkich innych przykładem, jak (...) to wyjaśniono w szkole" (Suchý 2017, 83). Nie brakło w tym opowiadaniu też wątków satyrycznych - np. w scenie, gdy dziewczęta rozmawiają ze swoim przewodnikiem, ideologiem z przekonania, Seriožą. Kiedy zapytały, czy go boli krzyż, ten odpowiedział, że u nich na tę część pleców mówi się grzbiet, bo nie trzeba do wszystkiego mieszać religii.

Odniesienia do negatywnych stereotypów widać w opowiadaniu Komu je $v$ krome horúco, toho doma zima bije (Komu jest w karczmie goraco, tego w domu zima bije, Suchý 2017, 84), w którym autor odnosi się do przekonania, że Rusini dużo pija. Tym samym Suchý mierzy się z tematem pojawiającym prawie we wszystkich opowiadaniach tomu. Bohater opowieści, jak wszyscy chłopi z wioski, lubi spędzać czas w karczmie, pijąc alkohol; bywa jednak, że traci kontrolę, upija się i robi sobie krzywdę, po czym przysięga rzucić picie: „Najlepiej jest żyć tak, aby wam bimbru własne dzieci nie wytykały” (Suchý 2017, 85). Kiedy wreszcie realizuje swoje postanowienie i zdaje sobie sprawę z negatywnego wpływu nałogu, przyjeżdża do niego gość, brat cioteczny z Ukrainy, i rzuca mu wyzwanie: picie za przyjaźn. Toasty za przyjaźń bohatera z ukraińskim krewnym były przyczyną ponownego wpadnięcia w szpony alkoholizmu. Wymowę opowiadania wzmacnia epizod, w którym kobieta oskarża pijącego: „Pijany jak Rosjanin, chla bimber jak Ukrainiec”, na co ten odpowiada: „Jaki ze mnie Rosjanin, jaki Ukrainiec! (...) Jestem uczciwym Rusinem (nawet zarejestrowałem się jako Rusin)" (Suchý 2017, 86).

W dalszej części opowiadania pokazane jest rozprzestrzenianie się nałogu w różnych warstwach społecznych. Bohater przestaje jednak pić, ponieważ musi brać leki z powodu bólu zęba. Wtedy nagle uświadamia sobie, ile stracił przez nałóg. Jednak abstynentem z przekonania staje się dopiero wtedy, gdy własne dziecko mówi mu, że chciałoby, aby go zawsze bolały zęby, bo wtedy nie pije. Udaje mu się tym razem wytrwać w postanowieniu, jednak zauważa problem u innych, np. u dentysty, który zaczął pić ze smutku po rozstaniu z żoną (zdradziła go i opuściła) - co ma być dowodem na rozpowszechnienie uzależnienia od alkoholu także wśród warstwy inteligenckiej. 
Okazuje się, że przyczyną nadmiernego sięgania po trunki jest samotność i nieumiejętność odnalezienia się we własnej skórze (Suchý 2017, 85).

Uprzedzenia i stereotypy sa przedmiotem artystycznej refleksji w całym tomie. Warto przywołać jeszcze opowiadanie dotyczące uprzedzeń na tle etnicznym i wyznaniowym. Otóż przy świątecznym stole dochodzi do „rywalizacji” przedstawicieli dwu wyznań: greckokatolickiego (dwóch mężczyzn) i prawosławnego (starzec) (Suchý 2017, 91). Bohaterowie spotykają się przy wspólnym stole i wiodą dysputy o tym, które z wyznań jest lepsze i dlaczego oraz co je charakteryzuje (język, zachowanie kapłanów - greckokatoliccy sa ,,jak panowie”, a prawosławny pop to „człowiek z ludu”, pracowity i zwyczajny itp.). Obrońca wyznania greckokatolickiego mówi: „Jeszcze nie widziałem mądrego prawosławnego popa", a obrońca prawosławia kontruje: „mądrego tylko mądry poznać może, a baran tylko barana”. Prawosławnego starca cechuje mądrość życiowa, nawołuje wszystkich do tolerancji i stwierdza, że wyśmiewanie innej wiary jest grzechem, a odmienni i źli są ludzie, a nie sama wiara: „Kiedy kochacie tylko swoje, a cudzego nie widzicie, to jest grzeszne" (Suchý 2017, 96). Jednak, jak się okazuje, mądrość starca, przejawiająca się m.in. w krytyce ludzkiej głupoty i płytkości myśli, nie przemawia do innych. Kiedy prawosławny starzec wychodzi, upada, po czym bezwładnie leży na ziemi. Nikt mu nie pomaga, mężczyzna umiera. Istotnym aspektem tej opowieści jest problematyka języka liturgii, a także związana z nią kwestia narodowościowa: „Jesteśmy Słowakami, ponieważ mieszkamy na Słowacji. A wy i Ukraińcy, i Rusnacy, i Rusini i bóg wie, kto jeszcze. Pomyliliście wiarę z polityką i narodowością, więc nie wiecie, jak z tego wyjść" (Suchý 2017, 97).

W opowiadaniach Ako som sa stal stalinistom (Jak rostałem stalinowcem, Suchý 2017, 99) i Ako som sa (skoro) stal komunistom (Jak (prawie) zostałem komunista, Suchý 2017, 143) opisane sa historyczne i społeczne warunki panujące w czasach sprawowania władzy przez partię komunistyczna; krytykowany jest brak wolności i charakter epoki - czasów socjalizmu, kiedy sukces mogli odnieść tylko ludzie mający wpływy, członkowie partii. Alter ego autora, Štefan Suchý, chce zostać członkiem partii, lecz to mu się nie udaje, mimo wielu starań, ukazanych zresztą z użyciem hiperboli. Autor opisuje reżim komunistyczny, a bohatera przedstawia jako nieudolną ofiarę własnych marzeń. O partii mówi się tu jak o obiekcie miłosnym, a jednocześnie krytykuje się ją i ośmiesza (przede wszystkim poprzez satyryczne opisywanie charakteru wpływowych polityków). Przyjrzyjmy się na przykład epizodowi, gdy bohater podczas zajęć na wieczorowym uniwersytecie marksizmu i leninizmu 
narzuca szybkie tempo nauki, ponieważ pragnie dostać się do partii własnymi siłami. Jednakże według wizji socjalistycznej trzeba umieć się dostosować do kolektywu (Suchý 2017, 150). Podobny rozdźwięk można też zauważyć między kreowanym wizerunkiem partii a stanem faktycznym: „Najmądrzejsze było podziwianie mądrości głupich i głębokie rozmyślanie nad głupotą względnie mądrych. Bardzo mądrych członków partii nigdy nie miałem szczęścia spotkać” (Suchý 2017, 150).

Suchý w omawianym opowiadaniu sięga także do charakterystycznej dla czasu przemian ustrojowych postawy, którą określa słowacki idiom „prevracanie kabátov", czyli zmienianie frontów politycznych, nieraz zupełnie zaskakujące i nieprzystające do wcześniejszych poglądów (np. członek partii komunistycznej po aksamitnej rewolucji wstępuje do partii katolickiej). Autor krytykuje tu nie tylko szereg ludzkich zachowań i słabości, ale także kulturę polityczną (m.in. ucieczki i „składanie” legitymacji partyjnych wpływowych członków partii tuż po rewolucji).

Opowiadanie, którego tytuł jest jednocześnie nazwa całego zbioru, Ako Rusini relaxujú (Jak Rusini odpoczywaja, Suchý 2017, 135), porusza najważniejsze dla społeczności rusińskiej na Słowacji problemy, tj. kwestie wiary, języka, liczebności tej mniejszości etnicznej, migracji za praca, a także relacji z innymi grupami etnicznymi i narodami. Przywołajmy tylko kilka przykładów stwierdzeń padających w tekście: „Nasza wiara jest miła Bogu, wasza wiara jest jak w wodzie dziura” (Suchý 2017, 139); ,nowoczesne jest po słowacku, nienowoczesne po rusińsku” (Suchý 2017, 139); „Rusinów jest mało, więc musza być uzdolnieni”" (Suchý 2017, 139); i tak np. prawosławnym przypisuje się sympatie komunistyczne, a grekokatolikom - chrześcijańsko-demokratyczne (zwolennicy partii Krest'anskodemokratické hnutie / Ruch chrześcijańsko-demokratyczny); wyśmiane są także deklaracje narodowościowe, często zależne od warunków ekonomicznych i finansowych -pada stwierdzenie, że gdyby gospodarka ukraińska lepiej sobie radziła i było tam więcej miejsc pracy, wszyscy Rusini uważaliby się za Ukraińców, ale ponieważ to na Słowacji jest wyższy poziom życia, wszyscy deklaruja, że są Słowakami).

\section{Perspektywy badawcze}

Już kilka przywołanych przykładów refleksji nad problematyką „mentalności” i tożsamości etnicznej w literaturze Rusinów na Słowacji sugeruje, że 
badanie tych zagadnień ma sens i może być płodne poznawczo. Na etapie badań wstępnych można powiedzieć, że do podstawowych cech rusińskiej tożsamości narodowej, która oczywiście rozwija się także poza twórczością artystyczną, należą: język rusiński (używanie go w mowie i w piśmie), przestrzeń (geograficznie wydzielony obszar, ale także związek z wiejskimi korzeniami), wiara i - dodajmy - sposób myślenia, który cechują optymizm, siła, determinacja; oczywiście cenione są także cechy i wartości ważne i dla innych obywateli Słowacji (zdrowie, miłość, moralność, siła, wykształcenie). We współczesnej rusińskiej twórczości literackiej istotne są również tradycje narodowe (przywiązanie do takich tradycji było z kolei typowe dla dawniejszej literatury słowackiej). Analiza przywołanych w artykule utworów pozwala też stwierdzić, że istnieją w kulturze Rusinów na Słowacji wyraźne tematy tabu, jak: aborcja, korupcja, ubóstwo, śmierć, starość, partnerskie relacje w starszym wieku.

Badanie wybranych tekstów Štefana Suchego pozwala wreszcie zidentyfikować kilka innych od przywołanych wcześniej cech, które można uznać za ważne dla tożsamości kulturowej Rusinów; są to: humor, spryt, pobożność w której ważny jest i rytuał, i bliska ludowości wiara w siłę wyższą oraz w jej przeciwieństwo (siły nieczyste), pracowitość, a także świadomość problemów społecznych (alkoholizm).

Podobnie jak w większości innych literatur narodowych, również w literaturze rusińskiej spotykamy się z pozytywnymi autostereotypami. Rusini w przywołanych dziełach pokonuja przeszkody, przezwyciężaja trudny los, znajduja rozwiązania problemów, zdobywają wykształcenie, dostają to, czego chca. Pozytywne cechy autoidentyfikacji równoważą sceptycyzmem, obawami o własna przyszłość, krytycznym nastawieniem do swojej grupy. Z kolei negatywne heterostereotypy pojawiają się rzadko w analizowanych tekstach, najczęściej zreszta jako człon przeciwstawny w relacji z grupami czy osobami spoza wspólnoty rusińskiej (miasto - wieś, bogactwo - ubóstwo, szczęście nieszczęścia), przy czym bywa, że bohaterowie walczą o swoje, nieraz przeciwko wszystkim i wszystkiemu, bez względu na kontekst narodowy. Kontekst etniczny czy narodowy traci też znaczenie, gdy mamy do czynienia ze zjawiskami ocenianymi jednoznacznie jako negatywne, jak np. chciwość, ateizm, brak wykształcenia.

Alena Blichová wymienia sześć najważniejszych obszarów literatury rusińskiej na Słowacji po 1989 roku, które obejmują: 1) poezję poświęconą budzeniu się tożsamości narodowej; 2) poezję i prozę opartą na folklorze; 3) prozę o tematyce wiejskiej; 4) metaforyczną poezję o różnorodnej tematyce; 
5) literaturę dla dzieci i młodziė̇y; 6) przekłady literatury (Blichová 2010, 72-73). Autorzy rusińscy, niezależnie od obszaru, do którego można by ich zaliczyć, dowodzą swoimi dziełami, że kwestie tożsamości narodowej, autoidentyfikacji i odrodzenia narodowego we współczesnej literaturze rusińskiej na Słowacji wciąż silnie wybrzmiewają. Dynamiczna sytuacja tej twórczości wymaga zajęcia się nią także z szerszego punktu widzenia, można np. starać się opisać tożsamość narodową Rusinów czy poszczególne jej elementy widoczne w dziełach literackich, a także skoncentrować się na związanych z omawianymi kwestiami zagadnieniach komunikacji międzykulturowej (m.in. w kontekście relacji Rusinów i innych grup etnicznych i narodowych na Słowacji).

Literatura

Anderson B., 1997, Wspólnoty wyobrażone. Rozważania o źródtach i rozprzestrzenianiu sie nacjonalizmu, przeł. Amsterdamski S., Kraków.

Bauman Z., 2010, Umèní q̌ivota, přel. Gabajová Z., Praha.

Berry J.W., Poortinga Y.H., Segall M.H., Dasen P.R., 2002, Cross-cultural psychology: Research and applications, New York.

Blichová A., 2010, Súčasná rusinska literatúra na Slovensku, in: Plišková A., ed., Rusínsky spisovný jazyke na Slovensku 1995-2010 a súčasná rusinska literatúra, Prešov.

Čeněk J., Smolík J., Vykoukalová, Z., 2016, Interkulturni psychologie. Vybrané kapitoly, Praha.

Hermanová M., 2015, Detom pre radost’ a poučenie. Poviedky pre deti, mládež a dospelých, Prešov.

Kosek J., 2011, Právo n(a) predsudek, Praha.

Košt'álová P., 2012, Stereotypní obrazy a etnické mýty. Kulturní identita Arménie, Praha.

Kseňak M., 2013, Spomienky a očakávania, Prešov.

Mal’covská M., 2002, Rusinske arabesky, Prešov.

Mal'covská M., 2007, Zelená fatamorgana, Užhorod.

Průcha J., 2010, Interkulturni komunikace, Praha.

Slivková I., 2015, Úvod do interkultúrnej komunikácie, Prešov.

Suchý Š., 1994, Rusinsky spevnike, Prešov.

Suchý Š., 2004, Az̧bukáreñ, Prešov.

Suchý Š., 2007, Slon na kyčere, Prešov.

Suchý Š., 2008, Nezábudka, Prešov.

Suchý Š., 2009, Most nad riekou času, Prešov.

Suchý Š., 2010, Azbuková mama, Prešov.

Suchý Š., 2014, Tretie krídlo, Svidník.

Suchý Š., 2016, Plody jesennej ₹ábrady, Svidník.

Suchý Š., 2017, Ako Rusíni relaxujú, Prešov. 